\title{
PERANCANGAN DAN IMPLEMENTASI PENCAHAYAAN UNTUK MENCAPAI KUALITAS VISUAL SISWA DI SMP N 2 CIBINONG, BOGOR
}

\author{
Endah Setyaningsih ${ }^{1}$, Henry Candra ${ }^{2}$ dan Fransiska I. Roesmaladewi ${ }^{3}$ \\ ${ }^{1}$ Program Studi Teknik Elektro, Universitas Tarumanagara \\ Email:endahs@ft.untar.ac.id \\ ${ }^{2}$ Jurusan Teknik Elektro, Universitas Trisakti \\ Email: henrycandra@trisakti.ac.id \\ ${ }^{3}$ Jurusan Psikologi, Universitas Tarumanagara \\ Email: fransiscar@fpsi.untar.ac.id
}

\begin{abstract}
ABSTRAK
Kondisi kurangnya pencahayaan pada ruang kelas banyak terjadi di berbagai sekolah SMP, baik di sekolah SMP negeri maupun swasta. Ruangan kelas yang digunakan untuk kegiatan belajar dan mengajar, hampir tidak memenuhi standar pencahayaan yang direkomendasi berdasarkan Standar Nasional Indonesia (SNI), yaitu sebesar 350 Lux (SNI, 2011). Rata-rata besarnya tingkat pencahayaan (Iluminansi/E) ruang kelas di beberapa SMP adalah kurang dari 150 Lux. Inipun bila sетиa lampu dinyalakan, karena kadang-kadang tidak semua lampu dinyalakan. Nilai sebesar 150 lux ini, kebutuhan daya setiap meter persegi adalah sekitar 6 Watt/m2, dengan menggunakan lampu golongan fluorescent seperti PL dan TLD. Artinya jika menggunakan lampu PL atau TLD untuk mencapai 350 lux dibutuhkan sekitar 15 watt/m2. Namun jika menggunakan lampu LED, untuk mencapai 350 lux dibutuhkan 10 watt/m2 atau kurang. Jadi penggantian dari lampu PL atau TLD ke lampu LED akan dapat menghemat penggunaan energi. Pengabdian kepada Masyarakat ini berupa implementasi pencahayaan di satu ruang kelas dan satu laboratorium di SMP N 2 Cibinong. Kegiatannya berupa perancangan pencahayaan dan retrofit lampu. Lampu yang digunakan adalah lampu LED 18 watt, dengan satu luminer untuk 2 lampu. Hasil dari kegiatan PKM ini adalah melalui retrofit lampu pada ruang kelas dan laboratorium, dapat dihasilkan iluminansi sekitar 300 lux. Di SMP N 2 Cibinong, terpasang 30 lampu LED di ruang kelas dan 18 lampu LED di laboratorium IPA. Adanya pencahayaan ini mampu membuat siswa merasa nyaman yang diharapkan mampu memenuhi kualitas visual siswa. Hal ini sesuai dengan hasil kuisioner dari para siswa, sebelum dan sesudah retrofit lampu.
\end{abstract}

Kata kunci: Pencahayaan, kualitas visual, iluminansi, SNI, retrofit lampu.

\section{PENDAHULUAN}

Berdasarkan penelitian berjudul 'Model Perilaku Hemat Energi pada Sektor Pendidikan dan Pengaruhnya terhadap Konservasi Energi Bidang Tata Cahaya dan Tata Udara, yang merupakan hibah desentralisasi penelitian unggulan yang telah dilaksanakan oleh tim pengusul (Fransiska Roesmaladewi, Endah Setyaningsih dan Lamto Widodo) tahun 2015 dan 2016, menghasilkan temuan bahwa masih banyak siswa dan guru SMP yang belum memahami makna hemat energi. Selain itu juga banyak yang belum tahu tentang istilah hemat energi. Hemat energi banyak diartikan sebagai menggunakan listrik sesedikit mungkin, sehingga ruangan hanya menggunakan lampu listrik rata-rata 4 buah dengan fluks luminous yang rendah. Akibatnya ruangan cenderung gelap, hal ini juga berlaku di ruang kelas untuk belajar mengajar. Setelah dilakukan pengukuran intensitas cahaya, ternyata ruangan ini mempunyai tingkat pencahayaan jauh lebih kecil dari standar SNI, sehingga ruang kelas kurang memenuhi kualitas pencahayaan ruang.

Kondisi ini banyak terjadi di berbagai sekolah SMP yang pernah diadakan pengamatan dan pengukuran, baik di sekolah SMP negeri maupun swasta. Ruangan kelas yang digunakan untuk kegiatan belajar dan mengajar, hampir tidak memenuhi standar pencahayaan yang direkomendasi 
berdasarkan Standar Nasional Indonesia (SNI), yaitu sebesar 350 Lux (SNI, 2011), seperti terlihat pada Tabel 1. Rata-rata besarnya tingkat pencahayaan (Iluminansi/E) ruang kelas di beberapa SMP adalah kurang dari 150 Lux. Inipun bila semua lampu dinyalakan, karena kadang-kadang tidak semua lampu dinyalakan. Nilai sebesar 150 lux ini, kebutuhan daya setiap meter persegi adalah sekitar $6 \mathrm{Watt} / \mathrm{m} 2$, dengan menggunakan lampu golongan fluorescent seperti PL dan TLD. Artinya jika menggunakan lampu PL atau TLD untuk mencapai 350 lux dibutuhkan sekitar $15 \mathrm{watt} / \mathrm{m} 2$. Namun jika menggunakan lampu LED, untuk mencapai 350 lux dibutuhkan $10 \mathrm{watt} / \mathrm{m} 2$ atau kurang (Setyaningsih, 2016, SNHP3M). Jadi penggantian dari lampu PL atau TLD ke lampu LED akan dapat menghemat penggunaan energi (Satwiko, 2008, SNI No. 04-6504-2001, Widodo, 2015).

Tabel 1. Tingkat Pencahayaan rata-rata, renderasi dan temperature warna yang direkomendasikan (SNI 6197-2011)

\begin{tabular}{|c|c|c|c|c|c|}
\hline \multirow{2}{*}{$\begin{array}{l}\text { Fungsi } \\
\text { Ruangan }\end{array}$} & \multirow{2}{*}{$\begin{array}{l}\text { Tingkat } \\
\text { Pencahayaa } \\
\text { n } \\
(\text { Lux) }\end{array}$} & \multirow{2}{*}{$\begin{array}{l}\text { Kelompo } \\
\text { k } \\
\text { Renderasi } \\
\text { Warna }\end{array}$} & \multicolumn{3}{|c|}{ Temperatur Warna (K) } \\
\hline & & & $\begin{array}{l}\text { Warm } \\
<3300\end{array}$ & $\begin{array}{l}\text { Warm White } \\
3300-5300\end{array}$ & $\begin{array}{l}\text { Cool } \\
\text { Daylight } \\
>5300\end{array}$ \\
\hline \multicolumn{6}{|c|}{ Lembaga Pendidikan } \\
\hline Ruang Kelas & 350 & 1 atau 2 & & $\mathrm{~V}$ & $\mathrm{~V}$ \\
\hline Perpustakaan & 300 & 1 atau 2 & & $\mathrm{~V}$ & $\mathrm{~V}$ \\
\hline Laboratorium & 500 & 1 & & $\mathrm{~V}$ & $\mathrm{v}$ \\
\hline $\begin{array}{l}\text { Ruang Praktek } \\
\text { Komputer }\end{array}$ & 500 & 1 atau 2 & & $\mathrm{v}$ & $\mathrm{v}$ \\
\hline $\begin{array}{ll}\text { Ruang } & \text { Lab. } \\
\text { Bahasa } & \end{array}$ & 300 & 1 atau 2 & & $\mathrm{~V}$ & $\mathrm{v}$ \\
\hline Ruang Guru & 300 & 1 atau 2 & & $\mathrm{~V}$ & $\mathrm{~V}$ \\
\hline $\begin{array}{ll}\text { Ruang } & \text { Olah } \\
\text { Raga } & \\
\end{array}$ & 300 & 2 atau 3 & & $\mathrm{v}$ & $\mathrm{v}$ \\
\hline Ruang Gambar & 750 & 1 & $\mathrm{~V}$ & $\mathrm{~V}$ & $\mathrm{~V}$ \\
\hline Kantin & 200 & 1 & & $\mathrm{~V}$ & $\mathrm{~V}$ \\
\hline
\end{tabular}

Pencahayaan di ruang kelas dan juga di laboratorium SMP N 2 Cibinong belum memenuhi syarat secara visual, yaitu belum memenuhi rekomendasi dari SNI. Kondisi pencahayaan yang kurang baik ini dalam jangka waktu yang lama akan mempengaruhi penglihatan/mata siswa dan juga guru. Penglihatan siswa dipaksa untuk berakomodasi sekuat mungkin untuk mengikuti pencahayaan yang kurang. Akibat akomodasi yang terus menerus, maka dapat menyebabkan gangguan pada mata siswa. Siswa SMP adalah siswa yang masih sangat muda, yaitu dengan kisaran usia 12 tahun sampai dengan 15 tahun. Suatu usia yang masih sangat panjang dalam memanfaatkan penglihatan untuk kehidupannya, dan usia yang harus terus menerus belajar untuk memperoleh ilmu pengetahuan. Bagi guru juga akan mengalami kesulitan dalam melaksanakan kegiatan belajar mengajar apabila banyak diantara siswanya kurang dapat melihat papan tulis dengan baik karena kurangnya pencahayaan.

Berdasarkan uraian di atas, dapat dikatakan bahwa permasalahan mitra ini bukan sesuatu yang tidak dapat dikerjakan karena permasalahan anggaran. Namun lebih disebabkan oleh kurang pahamnya sekolah mitra terhadap kenyamanan visual. Selain itu kurangnya pengetahuan tentang Standar SNI, khususnya bidang pencahayaan dan bahwa ada standar yang merekomendasikan tentang iluminansi (dalam satuan lux) untuk semua kegiatan di dalam ruangan. Setelah adanya penelitian tentang perilaku yang telah dilakukan oleh tim pengusul tahun 2015 dan 2016, telah 
memberikan gambaran yang lebih luas tentang hemat energi. Dalam hal ini juga adanya pengukuran iluminansi ruang kelas dan laboratorium menggunakan alat ukur cahaya yaitu lexmeter, hasilnya jauh dibawah standar SNI. Berdasarkan pengukuran ini terlihat bahwa hampir semua ruang belajar mengajar di SMP N 2 Cibinong kurang sesuai dengan standar SNI.

\section{METODE PELAKSANAAN}

1. Mendiskusikan dengan sekolah mitra untuk menyediakan satu ruang kelas dan atau satu laboratorium yang akan di jadikan obyek perbaikan.

2. Merancang pencahayaan ruang kelas dan atau laboratorium sesuai no. 1

3. Menentukan jenis dan bentuk lampu LED yang sesuai untuk ruang kelas dan atau laboratorium

4. Melakukan retrofit lampu dengan cara memasang lampu TL-LED di ruang kelas dan atau laboratorium, sesuai dengan perancangan untuk mengganti lampu fluorescent PL atau TL yang terpasang.

5. Memastikan hasil pemasangan lampu dengan melakukan pengukuran iluminansi (E) dan mencocokkan hasilnya dengan standar SNI yaitu mencapai 350 lux.

\section{HASIL DAN PEMBAHASAN RETROFIT LAMPU RUANG KELAS DAN LABORATORIUM IPA}

Ukuran ruang kelas yang disediakan untuk dilakukan retrofit lampu oleh SMP N 2 Cibinong adalah $(9 \times 7 \times 3 \mathrm{~m})$. Saat ini terpasang lampu CFL/PL, yang dipasang secara mounting surface/menempel plafon. Standar yang digunakan, jika menggunakan SNI, maka tingkat pencahayaan/iluminansi (E) ruang kelas adalah 350 Lux. Namun pada pelaksanaan PKM ini, digunakan iluminansi ruang kelas adalah 300 lux, lebih rendah dari pada standar SNI. Hal ini dilakukan karena pada kenyataan di berbagai ruangan jarang sekali ditemui ruangan yang iluminansinya mencapai $350 \mathrm{Lux}$, selain itu dikhawatirkan nantinya penggunaan daya listrik sekolah akan jauh lebih besar daripada sebelumnya. Gambar 1, menunjukkan kondisi ruang kelas SMP N 2 Cibinong saat ini, menggunakan lampu TLD 36 Watt.
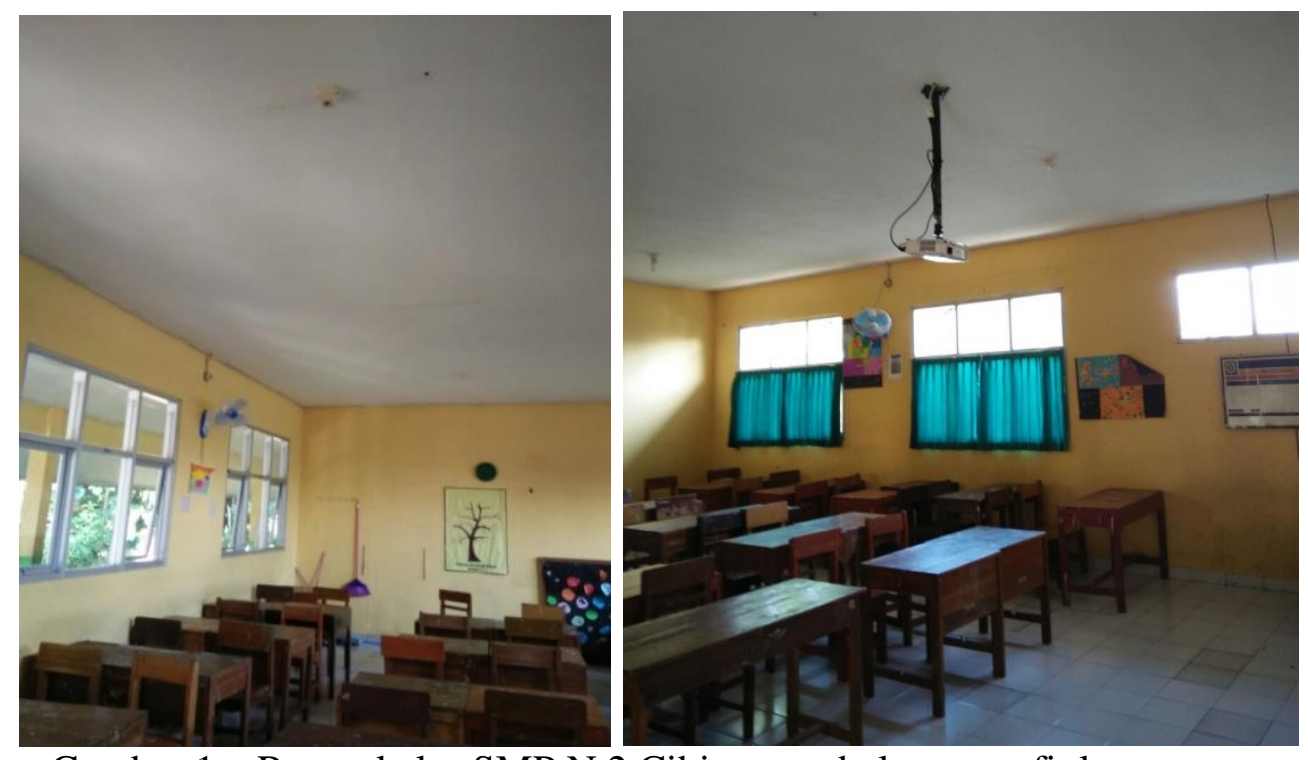

Gambar 1. Ruang kelas SMP N 2 Cibinong sebelum retrofit lampu

Hasil Simulasi dengan software Dialux (lihat Gambar 2), diperoleh Iluminansi (E) ratarata adalah 316 Lux dan kemerataan cahaya adalah 0,573. Hasil ini sudah sesuai dengan standar 
yang digunakan. Sedangkan hasil False Color Rendering ruang kelas SMP N2 Cibinong, dapat dilihat pada Gambar 3. Lampu yang dipakai adalah lampu LED 18 watt. Luminernya adalah $2 \mathrm{x}$ 18 watt, yaitu satu luminer dengan 2 lampu (lihat Gambar 4), yang dipasang menempel pada plafon (surface mounted). Lampu ini merupakan CSR dari PT Honoris Indonesia, yang dikenal sebagai PT Hori, yaitu pabrikan lampu lokal (Indonesia). Total lampu CSR ini adalah 96 buah lampu TL LED, dengan daya 18 Watt, dengan fluks luminous sebesar 1720 lumen. Daya lampu TL LED 18 watt setara dengan lampu TLD 36 watt (fluks luminousnya 1600 lumen). Setelah lampu dari PT Hori yang telah dikirim ke SMP N 2 Cibinong, maka dilakukan penyerahan dari pelaksana PKM ke salah satu wakil dari SMP N2 Cibinong, yaitu sebanyak 48 buah lampu dan 48 lampu lainnya diserahkan ke SMP Mardi Waluya. Gambar 5, adalah suasana ruang kelas SMP N 2 Cibinong setelah retrofit lampu. Pemasangan lampu ini sesuai dengan hasil simulasi yaitu dalam $3 \times 3$ deret luminer, dengan satu luminer terdiri dari 2 lampu TL LED 18 watt. Jadi total daya lampu untuk ruang kelas ini adalah $9 \times 2 \times 18$ watt $=324$ watt. Hasil retrofit lampu ruang kelas telah mencapai tingkat pencahayaan rata-rata lebih dari 300 Lux. Pre test dan post test dengan menggunakan kuisioner diberikan pada para siswa, yaitu sebelum dan setelah adanya retrofit lampu. Berdasarkan hasil kuisioner, para siswa menyatakan ruangan jauh lebih terang dari sebelumnya, dan menyatakan pencahayaannya sangat baik.

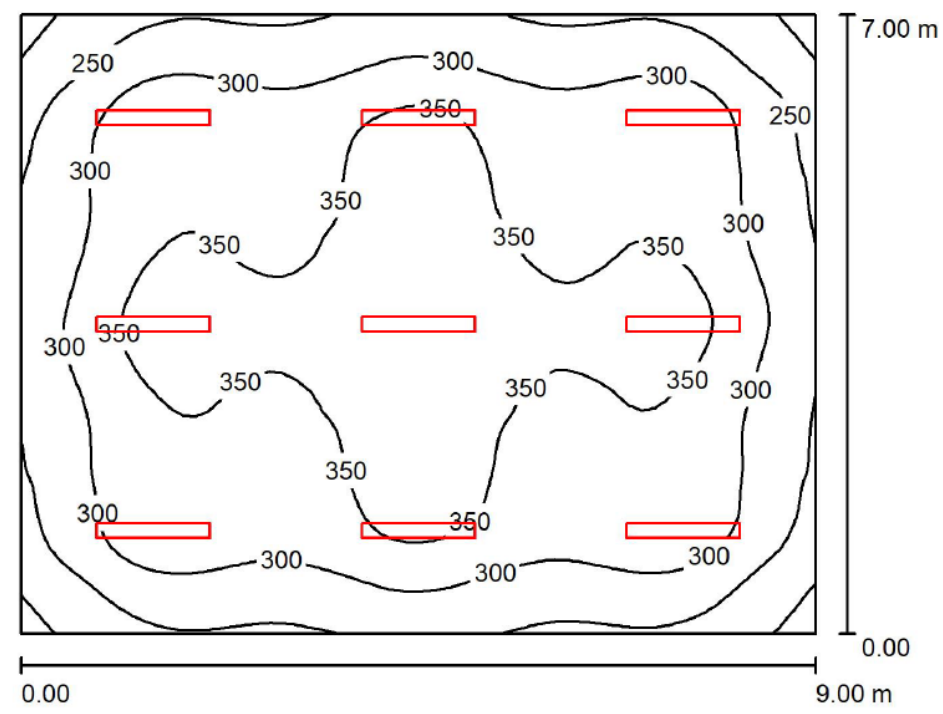

(a)

Height of Room: 3.000 m, Mounting Height: 3.000 m, Light loss factor: 0.80

\begin{tabular}{|c|c|c|c|c|c|}
\hline Surface & $\rho[\%]$ & $\mathrm{E}_{\mathrm{av}}[\mathrm{IX}]$ & $\mathrm{E}_{\min }[\mathrm{IX}]$ & $\mathrm{E}_{\max }[\mathrm{Ix}]$ & u0 \\
\hline Workplane & 1 & 316 & 181 & 399 & 0.573 \\
\hline Floor & 20 & 278 & 179 & 338 & 0.643 \\
\hline Ceiling & 80 & 94 & 61 & 462 & 0.648 \\
\hline Walls (4) & 50 & 187 & 112 & 282 & 1 \\
\hline $\begin{array}{l}\text { Workplane: } \\
\text { Height: } \\
\text { Grid: } \\
\text { Boundary Zone: }\end{array}$ & $\begin{array}{l}0.800 \mathrm{~m} \\
64 \times 64 \\
0.000 \mathrm{~m}\end{array}$ & & & & \\
\hline
\end{tabular}




\section{Luminaire Parts List}

$\begin{array}{rrlrrr}\text { No. } & \text { Pieces } & \text { Designation (Correction Factor) } & \Phi \text { (Luminaire) }[\mathrm{Im}] & \Phi \text { (Lamps) [lm] } & \text { P [W] } \\ 1 & 9 & \text { PT. Honoris Industry 2 } \times 18 \mathrm{~W} \text { LED - } 2 \times 18 \mathrm{~W} & 3440 & 3440 & 35.2 \\ & (1.000) & \text { Total: } 30960 & \text { Total: } 30960 & 317.2\end{array}$

Specific connected load: $5.03 \mathrm{~W} / \mathrm{m}^{2}=1.59 \mathrm{~W} / \mathrm{m}^{2} / 100 \mathrm{~lx}$ (Ground area: $63.00 \mathrm{~m}^{2}$ )

(b)

Gambar 2. Hasil simulasi ruang kelas SMP N 2 Cibinong (a) rancangan ruang kelas

(b) nilai iluminansi ruang kelas
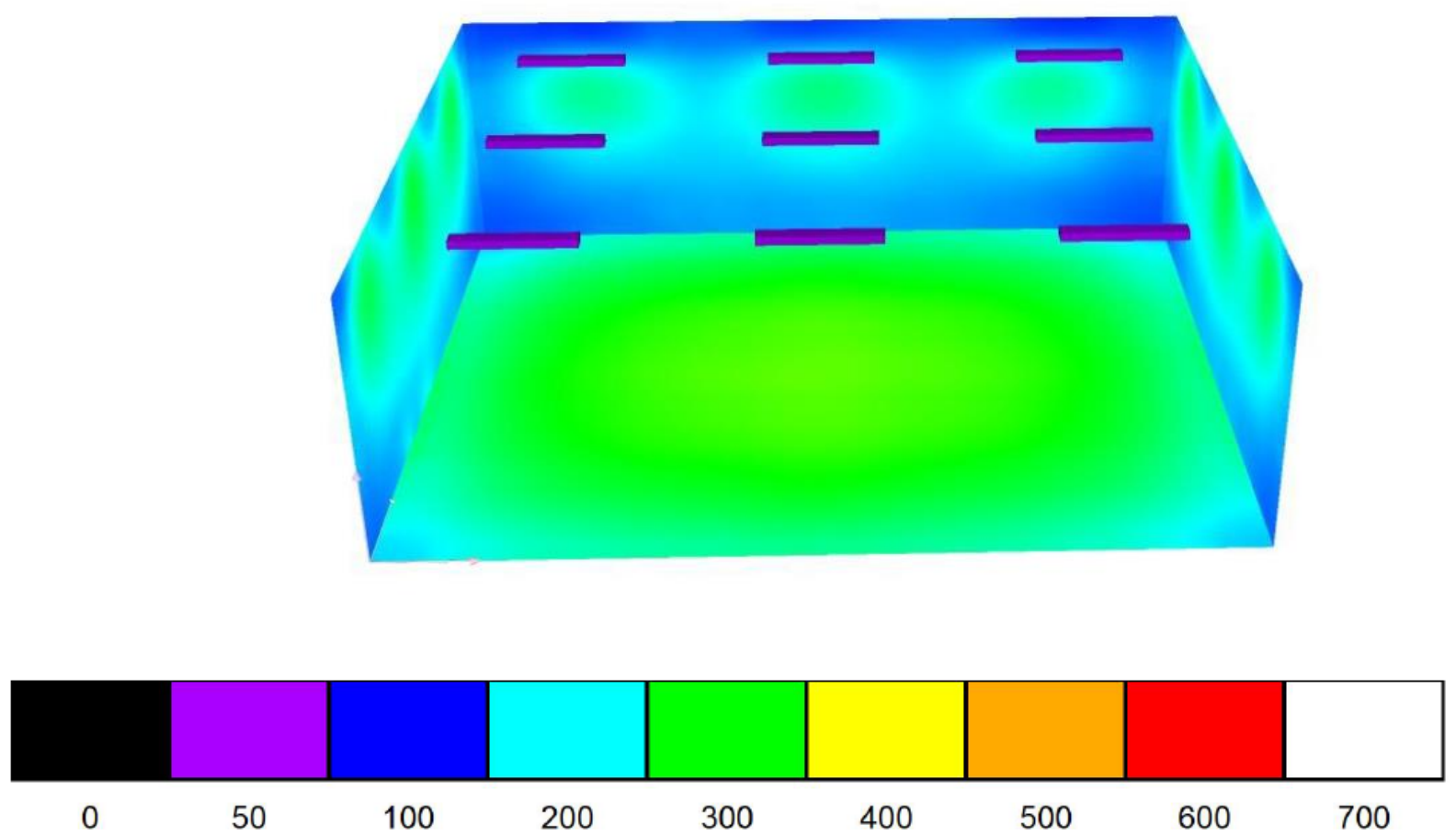

Gambar 3. Hasil False Color Rendering Ruang Kelas SMP N2 Cibinong

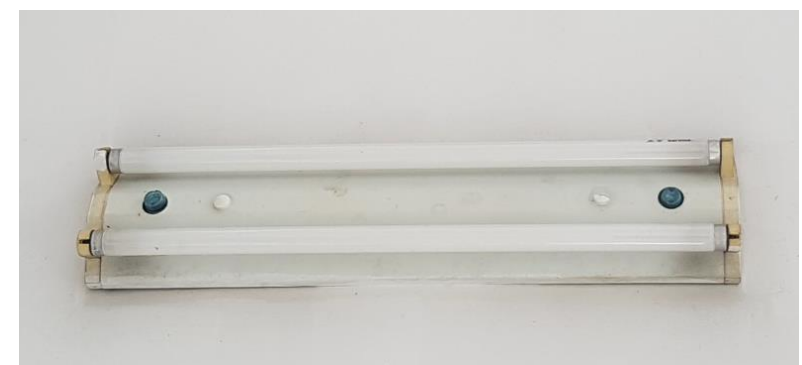

(a)

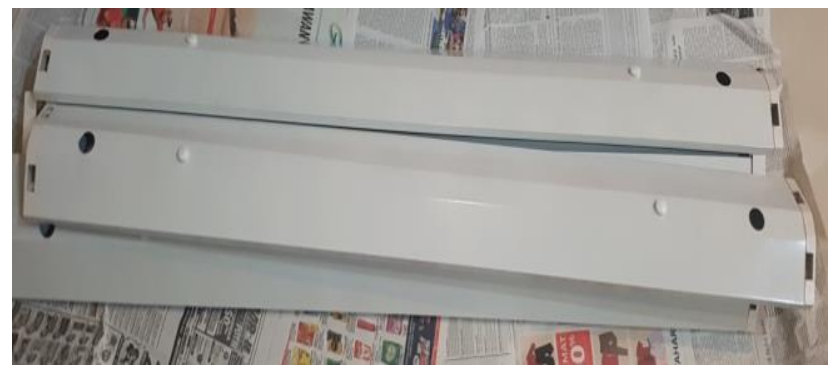

(b)

Gambar 4. Contoh satu luminer dengan 2 lampu (a) luminer 9 watt dan (b) luminer 18 watt 

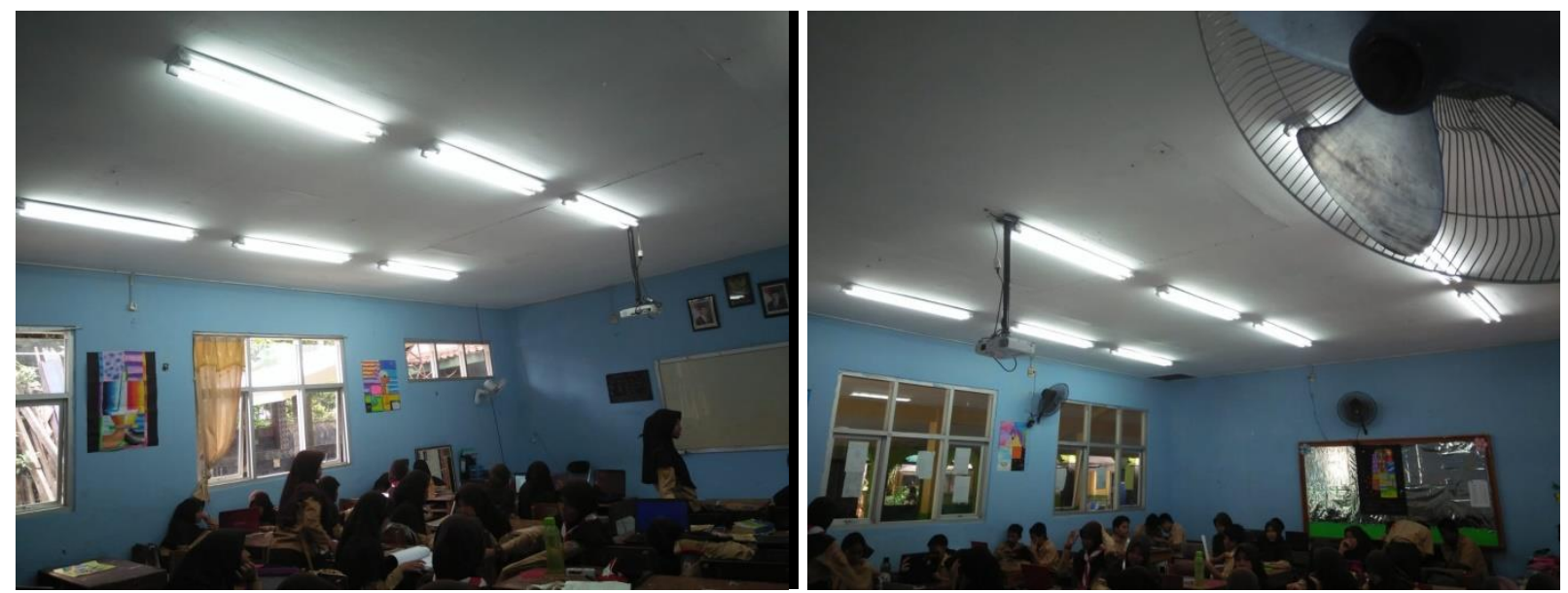

Gambar 5. Ruang kelas SMP N 2 Cibinong setelah retrofit lampu

Ukuran Ruang Laboratorium IPA adalah (15 x 8 x 3 m). Saat ini terpasang lampu CFL/PL, yang dipasang secara mounting surface/menempel plafon. Kondisi laboratorium IPA sebelum retrofit, nampak seperti pada Gambar 6. Hasil Simulasi dengan software Dialux, diperoleh E ratarata 301 Lux (Gambar 7). Lampu yang digunakan adalah lampu LED 18 watt. Luminernya adalah 2 x 18 watt (Kap tipe V), yaitu satu luminer dengan 2 lampu, yang dipasang menempel pada plafon (surface mounted). Gambar 8. Kondisi ruang laboratorium IPA setelah retrofit lampu.
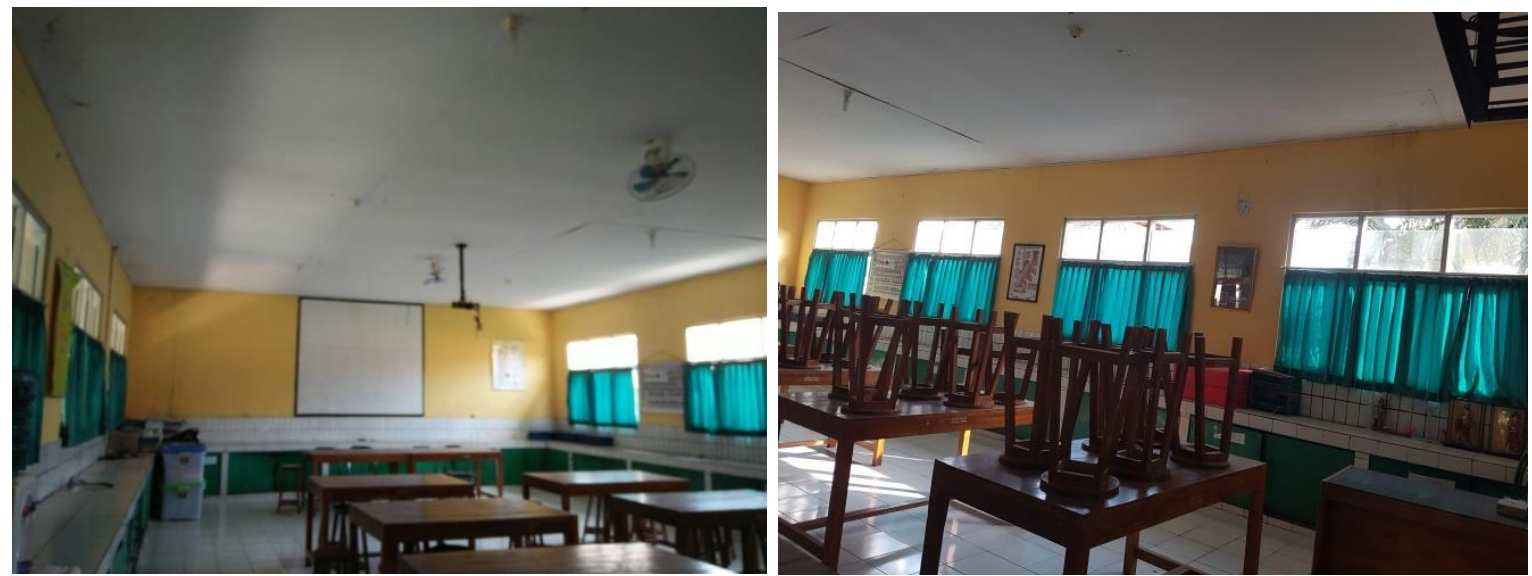

Gambar 6. Kondisi ruang laboratorium IPA sebelum retrofit

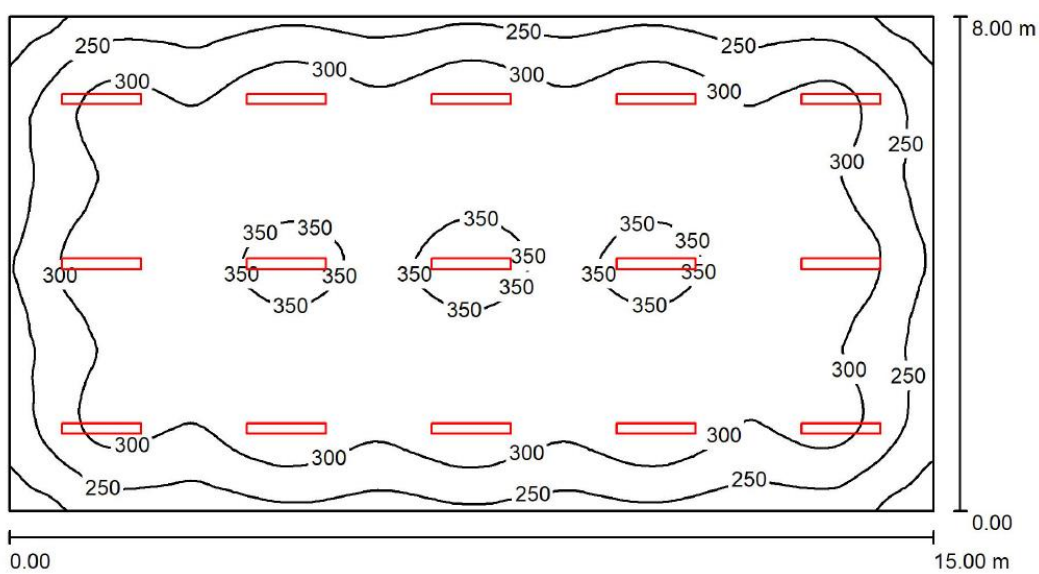

(a) 


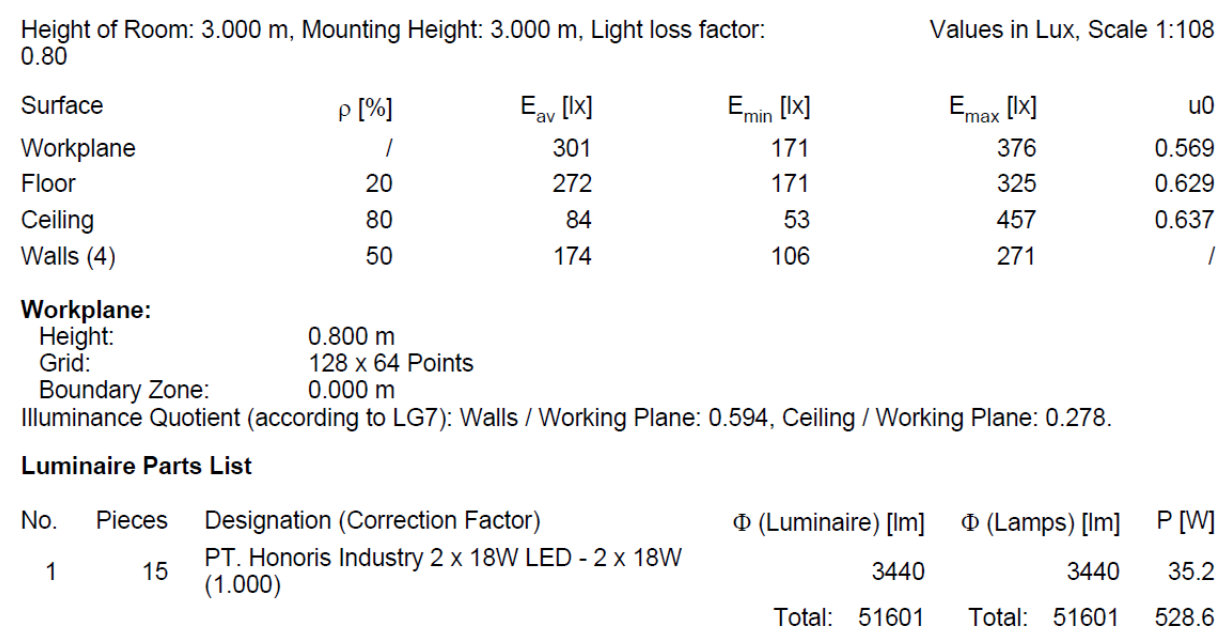

Specific connected load: $4.41 \mathrm{~W} / \mathrm{m}^{2}=1.46 \mathrm{~W} / \mathrm{m}^{2} / 100 \mathrm{~lx}$ (Ground area: $120.00 \mathrm{~m}^{2}$ )

(b)

Gambar 7. Hasil simulasi laboratorium IPA SMP N 2 Cibinong (a) rancangan ruang laboratorium (b) nilai iluminansi laboratorium
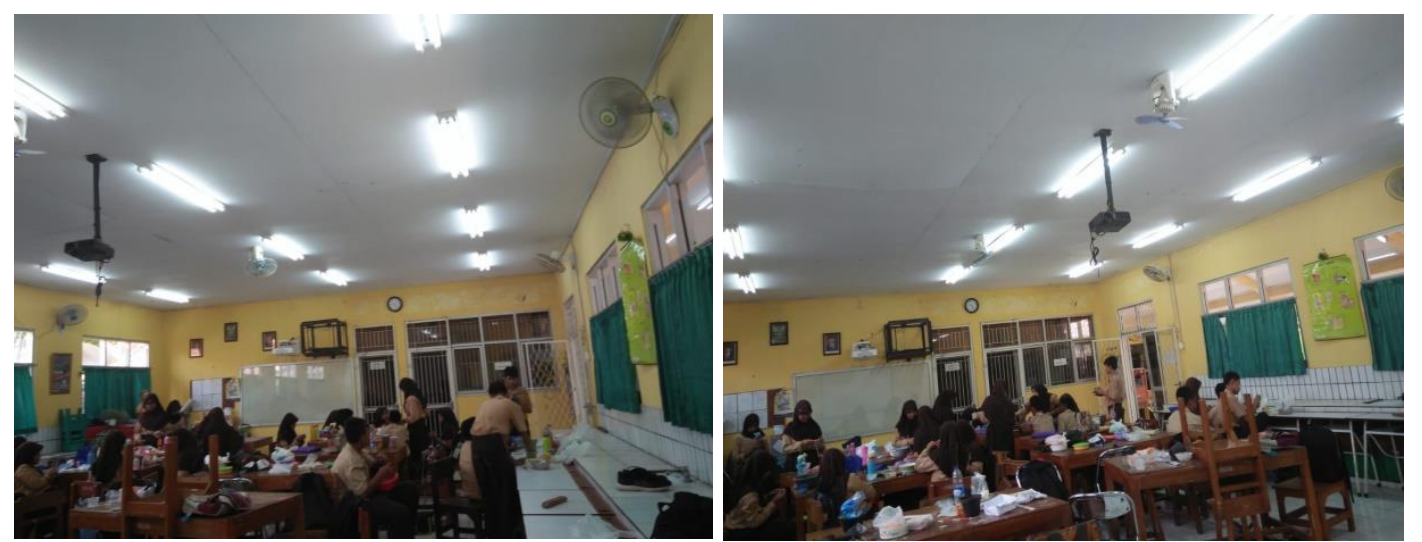

Gambar 8. Kondisi ruang laboratorium IPA setelah retrofit lampu

\section{KESIMPULAN DAN SARAN}

- Melalui retrofit lampu pada ruang kelas dan laboratorium, dapat dihasilkan iluminansi sekitar 300 lux.

- Di SMP N 2 Cibinong, terpasang 30 lampu di ruang kelas dan 18 lampu di laboratorium IPA, dengan luminer (2 x 1 lampu TL-LED 18 Watt).

- Adanya pencahayaan ini mampu membuat siswa merasa nyaman, yang diharapkan mampu memenuhi kualitas visual siswa. Hal ini sesuai dengan hasil kuisioner dari para siswa, sebelum dan sesudah retrofit lampu.

Ucapan Terimakasih, kepada:

- Kemenristek Dikti, atas bantuan dana hibah guna pelaksanaan PKM 2018

- PT Honoris Indonesia (PT Hori), atas bantuan pengadaan lampu TL-LED, sebagai bagian CSR perusahaan.

- DPPM Universitas Tarumanagara, atas bantuan dana pendampingan guna memperlancar kegiatan PKM ini. 


\section{REFERENSI}

Roesmaladewi, Setyaningsih dan Widodo, 2015 dan 2016, Model Perilaku Hemat

Energi Pada Sektor Pendidikan dan PengaruhnyaTerhadap Konservasi Energi Bidang Tata Cahaya dan Tata Udara, Penelitian Unggulan Hibah Dikti.

Satwiko, Prasasto, 2008, Fisika Bangunan, Penerbit Andi, Yogyakarta

SNI No. 04-6504-2001, 2001, Lampu swa-balast untuk pelayanan pencahayaan umumPersyaratan keselamatan, Badan Standarisasi Nasional.

SNI No. 6197-2011, Konservasi enrgi pada Sistem Pencahayaan, 2011

Setyaningsih dan Wardhani, 2015. Penghematan Energi untuk Air Conditioning dan Lampu Serta Perbaikan Lampu CFL di SMP Negeri 109 Jakarta Timur, Seminar Nasional Hasil Penerapan Penelitian dan Pengabdian Pada Masyarakat (SNHP3M), UniversitasTarumanagara.

Widodo, Setyaningsih dan Dewi, 2015. Ergonomic Aspect Of Physical Environment In Junior High School (Between Individual Comfort And Saving Energy Behavior), 2nd Internasional Conference on Engineering of Tarumanagara, Jakarta, 22-23 Oktober 2015 